\title{
THE ROLE OF COFFEE BASED AGROFORESTRY SYSTEM IN TREE DIVERSITY CONSERVATION IN EASTERN UGANDA
}

\author{
WORKU JANKA NEGAWO ${ }^{1,2}$, DEJENE NIGATU BEYENE ${ }^{2}$ \\ ${ }^{1}$ Department of Geosciences and Natural Resources Management, University of \\ Copenhagen, Denmark, e-mail: workujanka@yahoo.com \\ ${ }^{2}$ Department of Natural Resources Management, Madda Walabu University, Bale Robe, \\ Ethiopia
}

Received: $7^{\text {th }}$ October 2016, Accepted: $15^{\text {th }}$ December 2016

\begin{abstract}
Agroforestry farming system comprises considerable cultivated land area in the tropics. Despite the economic and social benefits of the system for farmers, it is also known to have an important role in the conservation of tree species. This study aims to evaluate the composition and distribution of tree species in coffee based agroforestry system to determine the potential for biodiversity conservation. To address the objective of this study, 57 sample plots in farmers' coffee field and 12 sample plots in forest reserve were surveyed in Eastern Uganda. The result shows that the number of indigenous tree species in coffee farms was lower than that of forest reserve. Similarly, tree species richness per plot, Shannon and Simpson diversity indexes of forest reserve were significantly $(\mathrm{p} \leq 0.05)$ higher than that of coffee farms. However, with the inclusion of exotic tree species, coffee farms were found to be significantly higher than that of forest reserve for the above diversity indexes. On the other hand, the distribution of tree species in the coffee farms were mainly dominated by few tree species indicating the need for measures that ensure the sustainability of those less represented tree species.
\end{abstract}

Keywords: biodiversity conservation; coffee agroforestry; coffee farming; agroforestry systems; tree species diversity

\section{INTRODUCTION}

The increasing loss of global biodiversity and ecosystem services has fuelled much exploration into the effectiveness of approaches that prevent species extinctions and ecosystem degradation while allowing for sustainable resource use (Adams \& Hulme, 2001; Berkes, 2009; Terborgh \& van Schaik, 2002). Although the extinction of species is natural process, current rates of extinction caused by human activities in the tropical rainforest alone is estimated at 1,000 to 10,000 times higher than the natural rate. This is an irreversible change and of unknown secondary consequences (Wilson, 1988).

As much as $90 \%$ of the terrestrial surface of the earth is outside of reserves and the majority of these are estimated to be maintained in some sort of managed state, usually forestry or agriculture (Western \& Pearl, 1989). Consequently, most of the biodiversity loss 
Negawo J. W., Beyene D. N.: The Role of Coffee Based Agroforestry System in Tree Diversity Conservation in Eastern Uganda

in the world today is occurring within managed land use systems largely due to the transformation of those systems from one form to another (Vandermeer et al., 2002).

Among major land use systems in the tropics, agroforestry technique is an important land use types by smallholder producers (Acharya, 2006; DeClerck et al., 2010; Schroth et al., 2004). In addition to enhancing the productivity of agricultural land, agroforestry systems have significant role in biological diversity conservation. Studies show that in humid tropical landscapes, coffee agroforestry system has a comparable conservation value to natural forests (Bhagwat et al., 2008; Perfecto et al., 1996; Donald, 2004; Klein et al., 2008). For example, varies studies on coffee agroforestry technique reported multiple functions of the system in conserving regional native tree species, provision of habitat for other species, as biological corridor between protected areas and alleviating resource-use pressure on conservation areas (McNeely \& Schroth, 2006; Bhagwat et al., 2008; Schroth et al., 2004). The role of coffee agroforestry system in delivering the above functions depends largely on the tree component of the farm.

In the highlands of eastern Uganda, smallholder farmers have been increasingly growing coffee on their farm lands since the introduction of Coffee arabica in the area as of early 1950s. Coffee plants are mostly grown under the shade of trees and banana plants in the area. The tree component of the farms usually comprises a variety of tree species that were either planted by farmers or established through natural regeneration. It seems that the coffee agroforestry systems of this area have also a considerable contribution towards tree diversity conservation similar to other coffee producing regions of the world. To realize the conservation role of this farming system and ensure its sustainability, however, deeper knowledge on the level of tree diversity that exists in the coffee farms has significant importance. This study was therefore conducted to explore the composition and species diversity of shade trees in coffee farms.

\section{MATERIALS AND METHODS}

\section{Description of the study area}

The study site is located in Eastern Uganda in the districts of Sironko and Mbale. The geographic coordinate of the study area lies at $1^{\circ} 6^{\prime} \mathrm{N}$ and $34^{\circ} 17^{\prime} \mathrm{E}$ at a distance of $220 \mathrm{~km}$ from Kampala. The area is mainly inhabited by smallholder farming communities. Coffee-banana mixed agroforestry system is the major type of crop grown in this area. The production of coffee was started in the early 1950 s according to local farmers.

Apart from settlement and farm lands, there is also a forest reserve on the boarder of the two districts and this reserve is called Namatale National Forest Reserve. The forest reserve is surrounded by small holder coffee farms except on the north side where it borders with Mount Elgon National park. According to National Forestry Authority of Uganda (NFA), the area of this forest reserve is estimated at 746 ha.

The study area has a mean annual rainfall of $1500 \mathrm{~mm}$ and mean temperature of $28^{\circ} \mathrm{C}$. The main rainy season extends from March to July with August and September receiving lower amount of rainfall (Mbale District Local Government, 2010). The topography of the study area comprises undulating landscapes. The altitude ranges from $1350 \mathrm{~m}$ to $1500 \mathrm{~m}$ above sea level. The soil is predominantly sandy clay loam soil based on USDA soil classification system (Sironko District Local Government, 2010). 


\section{Sampling Design}

To establish sample plots in the coffee farms, major coffee growing villages were first identified on the boundaries of the forest reserve. In order to identify these villages, two focus group discussions consisting of 7 and 9 individuals from the local farmers and village chiefs were conducted in both districts. Following the group discussion, nine coffee growing villages that boarder with the forest reserve were selected for the study. Among these villages, six of them were in Sironko district and the remaining three villages were in Mbale district (Table 1).

Table 1: Name of villages involved in the study and number of sampled plots

\begin{tabular}{lcc}
\hline Village names & District & Number of plots \\
\hline Bujibedi & Sironko & 4 \\
Kibo & Sironko & 6 \\
Majenga & Sironko & 3 \\
Bumalunda & Sironko & 15 \\
Bumungaswe & Sironko & 4 \\
Bubalinganga & Sironko & 5 \\
Bumudoma & Mbale & 6 \\
Bumoteka & Mbale & 8 \\
Mayenze & Mbale & 6 \\
Total & $\mathbf{2}$ & $\mathbf{5 7}$ \\
\hline
\end{tabular}

To establish sampling plots in coffee farms, transect lines were laid at a distance of $100 \mathrm{~m}$ from each other across the villages and coffee farms. A number of transects were then randomly selected from these transects. On the randomly selected transect lines points were systematically marked at $50 \mathrm{~m}$ interval (Fig. 1). From the marked points, 57 points were randomly selected for all the villages combined. Sampling plots of $20 \mathrm{~m}$ x $25 \mathrm{~m}$ were established at each selected points for tree parameter measurements. On the other hand, sample plots for the forest reserve were randomly selected using GPS points marked on the map of the forest reserve. The sampling plot size for the forest reserve was similar to that of coffee farms. But the number of the sample plot for the forest reserve was 12 . The reason for the lesser sampling plots in the forest reserve was due to the area of the forest reserve which is much smaller as compared to the area of coffee farms studied. 
Negawo J. W., Beyene D. N.: The Role of Coffee Based Agroforestry System in Tree Diversity Conservation in Eastern Uganda

Fig. 1: A sample design showing the sampling method and design used for coffee farm sampling plot

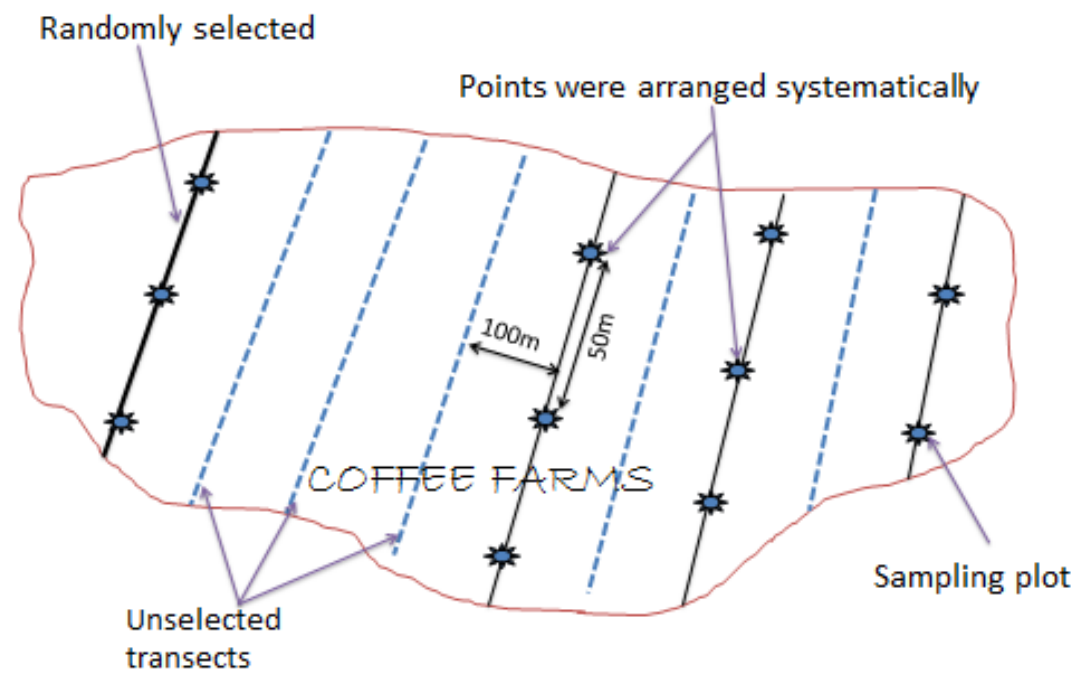

\section{Data collection}

A total of 69 sample plots, 57 in coffee farms and 12 in forest reserve, were surveyed for tree parameters. Trees with height greater than $2 \mathrm{~m}$ were measured for diameter at breast height $(\mathrm{DBH})$ and crown width. These trees represent the majority of trees that provide shade for coffee. The crown measurement of individual trees was done two times perpendicular to each other and the average of these was taken for further analysis. The number and names of tree species with height greater than $0.5 \mathrm{~m}$ in each plot were also recorded for species diversity analysis.

For all the recorded trees, a specimen was collected and its local name was identified on the field with the help of farmers and Namatale Forest Reserve rangers. The specimens were identified following the botanical book of Katende et al. (1995) and also by the support of botanists at the NFA and National Forestry Resources Research Institute of Uganda (NaFORRI).

\section{Data Analysis}

The structure of shade trees were analysed based on tree density, crown area and importance value index (IVI). The means of tree density and crown area were calculated per unit hectare of farm land. Whereas, IVI was calculated as the sum average of relative dominance (RD), relative abundance (RA) and relative frequency (RF) of each tree species.

$$
\operatorname{IVI}(\%)=(\mathrm{RD}+\mathrm{RA}+\mathrm{RF}) / 3
$$

According to Curtis and McIntosh (1950) the above terms are defined as follows:

Relative dominance for a given species is the ratio of the total basal area of a given species to the total basal areas of all species together in per cent. Whereas, relative abundance (density) is the ratio of the number of stems of individual species to the total number of stems 
of all species (in percent). And finally, relative frequency is the frequency of a given species as compared to the total frequencies of all the species combined (in per cent).

For the quantitative analysis of tree species in the two land use types, a number of diversity indexes were employed. Species diversity indexes commonly applied for species distribution analyses include Shannon, Simpson, species richness and Sorenson indexes. Shannon (using natural logarithms) and Simpson indexes (the reciprocal form) were computed using EstimateS 8.2 (Colwell, 2006). The result of EstimateS 8.2 for the two indexes were then run in SPSS 16.0 by using independent samples t-test to check if the mean indexes of the two land use types were significantly different from each other. Similarly, species richness (R) per plot of coffee farms and forest reserve was run in SPSS 16.0 using independent samples $\mathrm{t}$-test to see if the means of species per plot for the sites were significantly different from each other.

On the other hand, the index of similarity among tree species of coffee farms and forest reserve was calculated using Sorensen index (S) as follows:

$$
\mathrm{S}=2 \mathrm{C} /\left(\mathrm{S}_{1}+\mathrm{S}_{2}\right)
$$

Where, $S_{1}$ and $S_{2}$ are the number of species in each land use type; $C$ is the total number of species shared by the coffee farms and the forest (Sorensen, 1948).

Shannon and Simpson indexes take the evenness of individuals into account in an area. However, species richness (R) does not take the distribution of species in to consideration. Species richness is the most sensitive to rare species whereas Simpson diversity is the least with Shannon diversity with an intermediate sensitivity (Colwell, 2006).

The total number of tree species observed $\left(S_{\text {obs }}\right.$ Mao Tau) with $95 \%$ lower and upper bound confidence intervals were computed from the species data of coffee farms and forest reserve by the use of EstimateS 8.2 (Colwell, 2006). Mao Tau is a mathematical equation (estimator) that provides the species frequency counts (Colwell et al 2012). Following this, individual-based rarefaction curves were plotted to see if the confidence intervals overlap or not so as to get a conservative statistical difference in species richness between the two land use types. Furthermore, sample plot-based rarefaction curves were also drawn to know whether the species accumulation curves reach an asymptote. It can be assumed that the total number of species in an area is basically observed when the species accumulation curve reaches asymptote. Sample plot-based rarefaction curves also provide information on the density of species observed (Colwell et al., 2012; Gotelli \& Colwell, 2001).

\section{RESULT}

\section{Overview of Coffee Production System}

Coffee agroforestry system is the main agricultural practice system in the study area. According to local farmers, coffee production was introduced into the area in the early $1950 \mathrm{~s}$. Prior to the start of coffee production, most current coffee farms (ca. $74 \%$ by the number of farm plots) were under banana plantation (Musa spp.). Even in the present time, banana is the most common grown crop with coffee plants. On average, the density of banana plant in coffee farm plot is about 395 plants per hectare and that of coffee is about 2,000 plants per hectare. In addition to banana, farmers also grow various tree species and crops intercropped with coffee. Tree species such as Cordia africana, Albizia gummifera, Artocarpus heterophyllus and crops like maize and beans are usually grown with coffee (Fig. 2). 
Negawo J. W., Beyene D. N.: The Role of Coffee Based Agroforestry System in Tree Diversity Conservation in Eastern Uganda

Fig. 2: Typical coffee agroforestry system of the study area (Bubalinganga village)

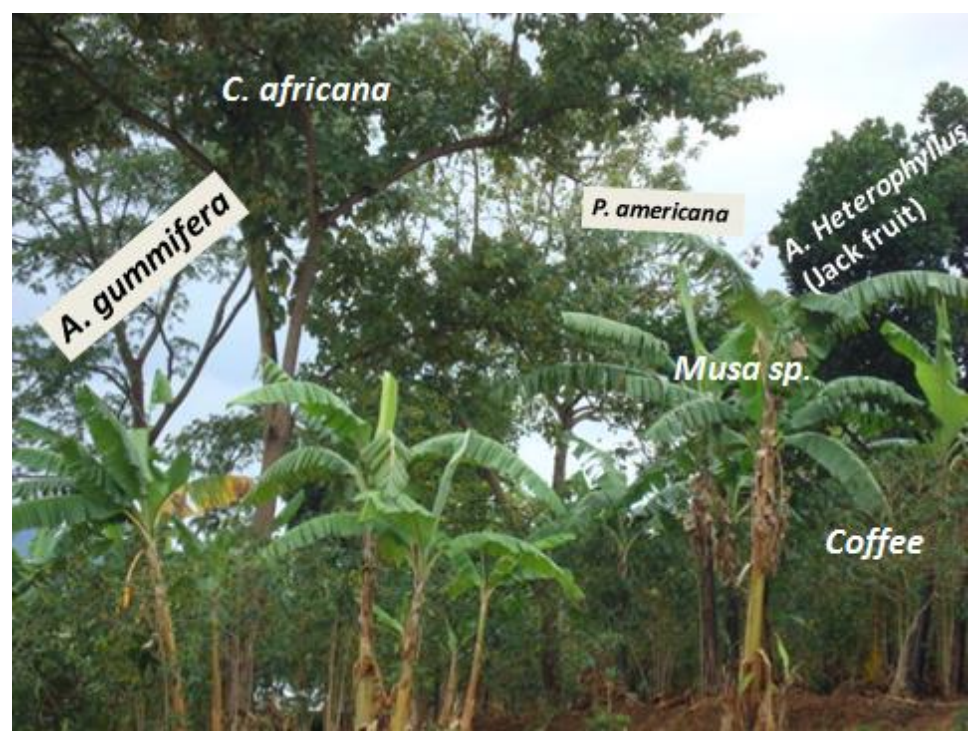

\section{STRUCTURE OF SHADE TREES}

\section{Density of Shade Trees}

The average tree density (height $>2 \mathrm{~m}$ ) of studied coffee farms were 116 individuals per hectare. In total 50 species of trees and shrubs were observed to be managed by farmers in coffee farms. From these, 42 tree species were higher than $2 \mathrm{~m}$ in height. The most abundant species among all shade tree species was Cordia africana (26 trees per ha) followed by Markhamia lutea and Cordia millenii with 12 and 9 trees per hectare, respectively (Fig. 3).

\section{Fig. 3: Average density of most abundant shade tree species in coffee farms}

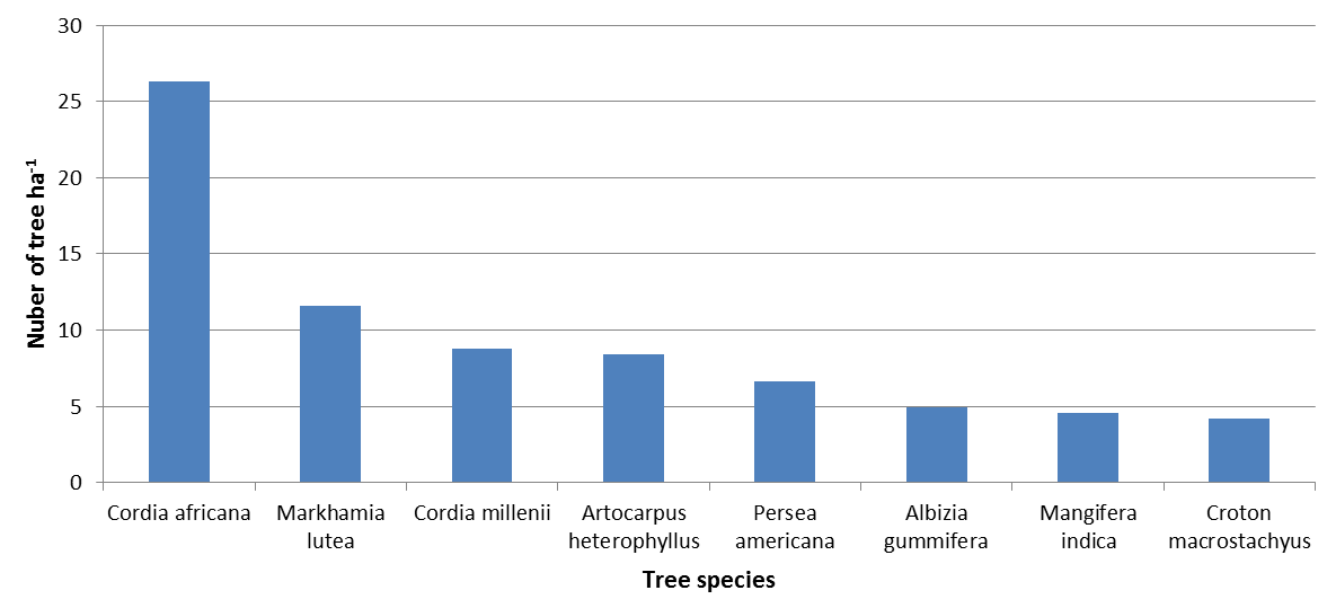




\section{Shade Tree Crown Area}

The crown area of tree species (with height $>2 \mathrm{~m}$ ) was about $21 \%$ of the total coffee farm area. From the total of 42 canopy tree and shrub species, the major proportion of crown cover was contributed by only three species. C. africana, $C$. millenii and A. gummifera were the dominant crown species with about $68 \%$ of the total tree species crown cover area (Fig. 4). These species were also dominant species for basal area. In general, $89 \%$ of shade cover was provided by only 9 tree species despite the large number of tree species grown in coffee farms.

Fig. 4: Dominant crown tree species

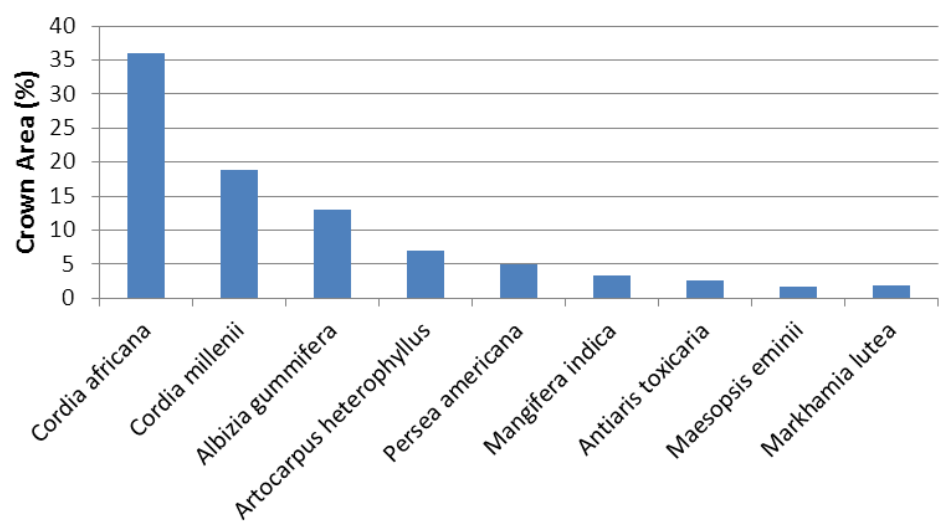

\section{IMPORTANCE VALUE INDEX}

Importance value index (IVI) of a species is a parameter to measure species overall relative dominance in an area. The most dominant species in the coffee farming system of the study area was C. africana with an IVI of $20 \%$ followed by M. lutea, C. millenii, A. heterophyllus and A. Gummifera (Fig. 5). About $77 \%$ of IVI of tree and shrub species in coffee farms was contributed by 12 species out of a total 50 .

Fig. 5: Dominant tree species according to Importance Value Index (IVI) in coffee farms

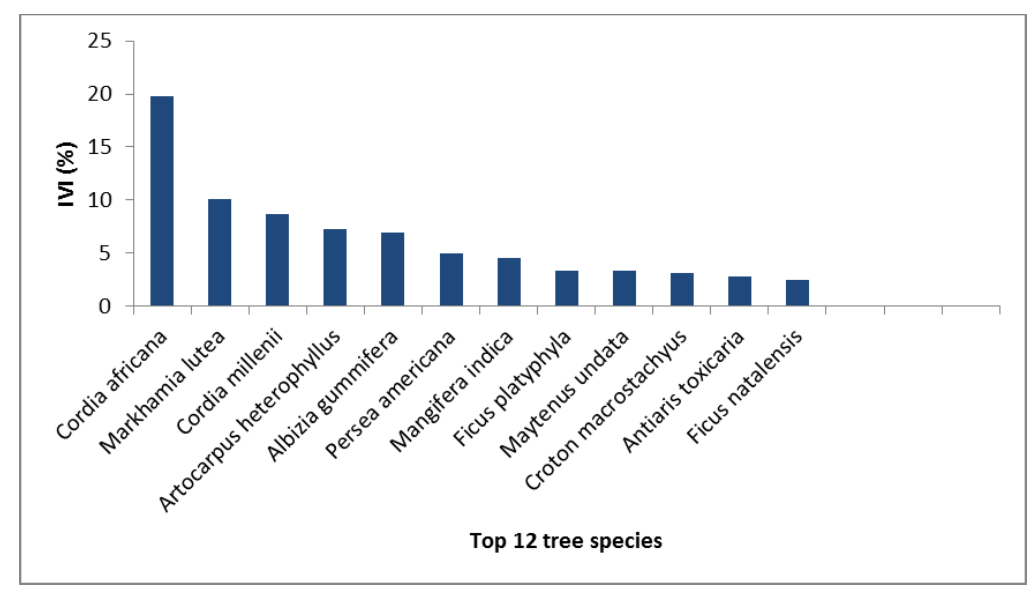


Negawo J. W., Beyene D. N.: The Role of Coffee Based Agroforestry System in Tree Diversity Conservation in Eastern Uganda

\section{Tree Species Composition of the Forest Reserve}

The forest stand of Namatale National Forest Reserve comprises a mix of different tree species with scattered mature trees. The forest stand shows an evidence of degradation such as incidences of forest fire and illegal logging as it was observed during the data collection. The most abundant tree species include Vernonia auriculifera (relative density of $28 \%$ ), Maesa lanceolate (9\%) and Blighia unijugata (8\%). Similarly, V. auriculifera and $M$. Lanceolate are the most frequent tree species with $7 \%$ relative frequency (Fig. 6). These two tree species are mostly abundant in degraded areas and on the edges of the forest. In general, 10 tree species from the total of 39 tree species made up $75 \%$ of the total stem number (relative density).

\section{Fig. 6: Relative density and relative frequency of the top 10 tree species}

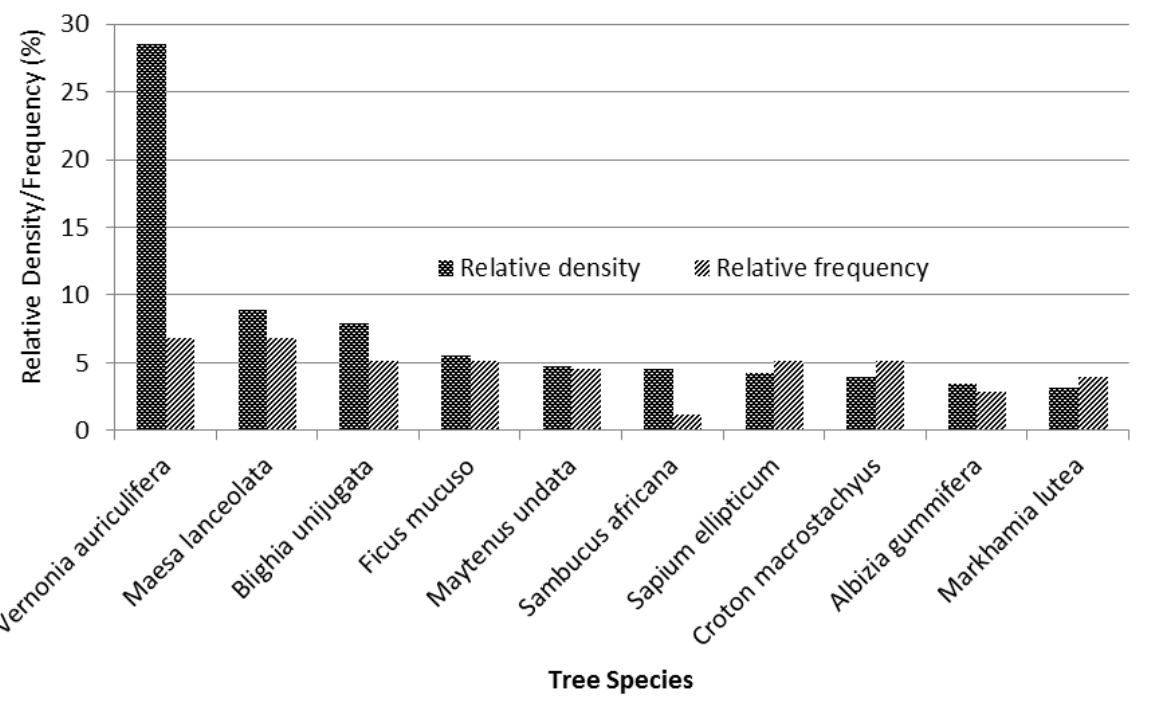

\section{Comparison of Tree Species Composition in the Two Land Uses}

A total of 63 tree and shrub species were recorded in the coffee farms and Namatale forest reserve. Among these species 7 were shrubs. Fifty (50) tree and shrub species were recorded in coffee farms alone. On the other hand, the number of species observed in the forest reserve was 39. A total of 1,433 individuals including seedlings, saplings, mature trees/shrubs and stumps were recorded in the coffee farms and forest reserve sampling plots.

From the total tree and shrub species encountered in both land use types, 46 species were indigenous to Uganda and 16 of them were exotic with one unidentified. All the 16 exotic species were recorded in coffee farms. This makes about one third of the total tree species in coffee farms. However, three of these species were also observed in the forest reserve. Sorenson index of similarity indicates that the two land use types were similar by about $56 \%$ of their species composition.

Moraceae and euphorbiaceae families were the most common species in the two land use types. The most frequent tree species in coffee farms include C. Africana, M. lutea, A. heterophyllus, P. Americana, M. indica, C. millenii and A. gummifera. These seven (7) tree species were encountered in at least one third of the coffee farms surveyed. Whereas, in 
the forest reserve 22 tree and shrub species were observed in at least one third of the sample plots. M. lanceolata and $V$. auriculifera were found in all plots of the forest reserve with exceptionally higher density.

The tree species richness $(R)$ per plot of the forest reserve $(R=14.6)$ was significantly higher $(\mathrm{p}<0.05)$ than that of coffee farms $(\mathrm{R}=5.7)$ implying the greater tree species richness of the forest reserve (Table 2).

Similarly, Simpson and Shannon indexes of diversity also show significant differences $(p<0.05)$ in tree species composition. Coffee farms revealed higher tree species diversity than the forest reserve based on these indexes (Table 2). On the other hand, these diversity indexes were also analysed for both sites without exotic tree species. In this case, the reverse of the above condition was observed. Both Shannon and Simpson diversity indexes of the forest reserve were found to be significantly higher than that of coffee farms. These exotic trees were planted by farmers mainly for their fruits.

Table 2: Characteristics of tree species in coffee farms and forest reserve

\begin{tabular}{lcc}
\hline \multicolumn{1}{c}{ Parameters } & Coffee farm & Forest Reserve \\
\hline Number of sample plots & 57 & 12 \\
Surveyed area (ha) & 2.85 & 0.6 \\
Total number of species recorded & 50 & 39 \\
& & \\
Average tree species richness (R) & $5.7^{\mathrm{a}}$ & $14.6^{\mathrm{b}}$ \\
Inverse Simpson index & $11.87^{\mathrm{a}}$ & $8.91^{\mathrm{b}}$ \\
Inverse Simpson index without exotic & $6.99^{\mathrm{a}}$ & $8.27^{\mathrm{b}}$ \\
species & $2.83^{\mathrm{a}}$ & $2.59^{\mathrm{b}}$ \\
Shannon diversity index & $2.36^{\mathrm{a}}$ & $2.53^{\mathrm{b}}$ \\
Shannon diversity index without & & 0.56 \\
exotic species & & \\
Sorenson similarity index & &
\end{tabular}

Mean indexes followed by different letters across rows were significantly different according to independent-samples $t$-test $(p \leq 0.05)$.

The individual-based rarefaction curves show that tree species richness in coffee farms does not significantly exceed the richness of forest reserve for sample sizes between 1 and 300 individuals conservatively based on overlapping confidence intervals of $95 \%$. However, it is clearly evident that the species richness of coffee farms was higher than that of forest reserve as the curve for coffee farms situated above that of forest reserve (Fig. 7, a).

On the other hand, sample-based rarefaction curves showed faster accumulation of species in the forest reserve than that of coffee farms (Fig. 7, b). This indicates that the density of species per sample plot for the forest reserve was higher than that of coffee farms. 
Fig. 7: Rarefaction curves for coffee farms and forest reserve:

a) Individual-based

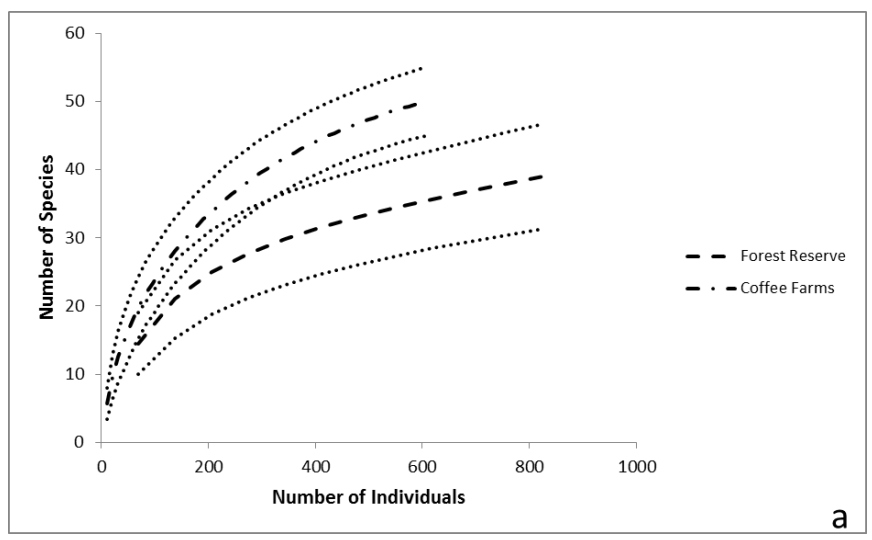

b) sample plot-based with $95 \%$ upper and lower bound confidence intervals (Mao Tau).

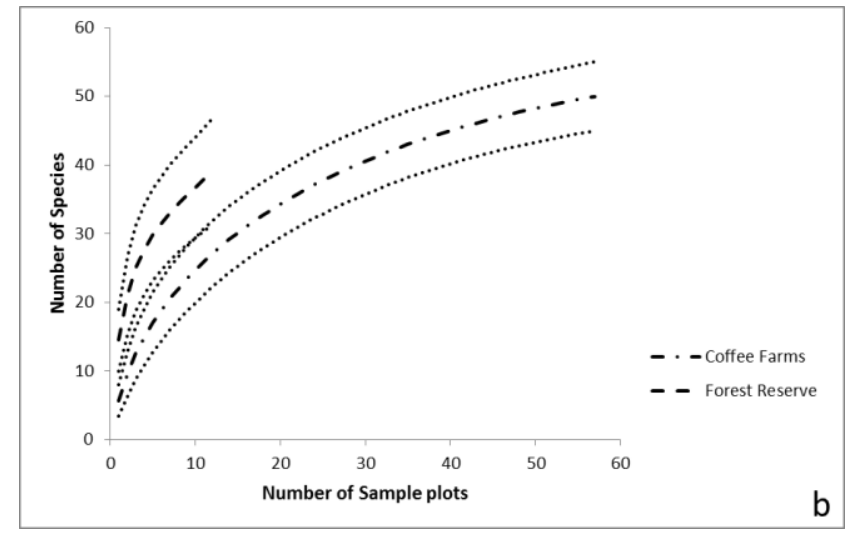

\section{DISCUSSION}

\section{Tree composition of coffee farms}

The result shows that the shade trees in coffee agroforestry system of the study area were an important feature of coffee production system and have continuous distribution across coffee farms. However, the characteristics of the shade trees differ in a number of ways in terms of tree density, stem diameter and crown width among the tree species.

The average density of 116 trees per ha in the coffee farms of the study area appears to be lower than the values reported for other coffee growing regions (Correia et al., 2010; Lopez-Gomez et al., 2008; Peeters et al., 2003). However, a comparable shade tree density of 100 to 150 trees per hectare was also reported in the Andean mountain of Venezuela (Escalante, 1985). A likely reason for the lower number of trees in the present study could be due to the high density of banana plant in the coffee farms. Moreover, intercropping of multiple annual crops with coffee could also be another reason for the lower density of shade 
trees. The lower density of trees creates free space for other crops growing under coffee plants.

The tree crown cover of $21 \%$ in the coffee farms also found to be lower than the recommended optimal shade cover range for coffee plants in other tropical regions. In Mexico, Soto-Pinto et al. (2000) observed that shade cover of 23 to $38 \%$ had a positive effect on coffee yields. Similarly, in Costa Rica the best yield was recorded under shade cover of $40 \%$ (Muschler, 1997). It appears that the low tree density in coffee farms is the major contributor for the low shade cover.

The importance value index shows the dominance of only few shade tree species in the coffee farms. The high IVI value of these tree species seems to relate to the farmers' conscious management of shade trees for its various benefits. This has an implication on the conservation efforts need to be made for the less beneficial and rare species.

\section{Tree diversity in the coffee farms and forest reserve}

This study revealed that considerable number of tree species are being managed and conserved in coffee farms. However, as compared to coffee farms in other regions the number of tree species observed in the study area appears to be lower. For example, in Veracruz, Mexico, the species richness of studied coffee farms reach up to 107 (Lopez-Gomez et al., 2008). Similarly, ninety four (94) mature tree species (DBH>10cm) were recorded in Geuinean coffee farms (Correia et al., 2010). On the other hand, Bandeira et al. (2005) reported 45 tree species which is comparable to the result of the present study. The difference in species richness could probably emanate from the differences in farm management and regional plant species pool variation (Williams-Linera, 2002).

Notably, in this study the number of tree and shrub species in coffee farms was higher than that of the forest reserve. Likewise, a study by Lopez-Gomez et al. (2008) found similar result where they recorded 107 tree species in coffee farms against only 62 tree species in forests. On the other hand, tree species diversity was found to be higher in forests than in coffee farms in other studies (Correia et al., 2010; Williams-Linera et al., 2005 cited in Lopez-Gomez et al., 2008). A likely reason for the fewer number of tree species in the forest reserve in the present study could be attributed to the fewer sample areas surveyed in the forest reserve relative to coffee farms. Moreover, the high number of exotic species observed in coffee farms could also be another contributing factor for the result as the possibility of those species to grow in forest is too low.

The forest reserve shows significantly higher species richness $(p<0.05)$ than coffee farms. Whereas, Simpson and Shannon indexes of diversity for coffee farms were significantly $(p<0.05)$ higher than that of forest reserve. However, similar analysis of species diversity without exotic species revealed the opposite of this result (Table 2). By excluding exotic trees, Shannon and Simpson diversity indexes of coffee farms were significantly lower $(p<0.05)$ than that of forest reserve.

From the individual-based rarefaction curves it appears that coffee farms have relatively higher species richness than forest reserve. On the other hand, sample plot-based rarefaction curves indicate higher species density in the forest reserve. The species rarefaction curves of both sites show that the curves are far from reaching asymptote indicating more sample plots needs to be observed to estimate the total number of species in both land uses. 
Negawo J. W., Beyene D. N.: The Role of Coffee Based Agroforestry System in Tree Diversity Conservation in Eastern Uganda

\section{CONCLUSION}

Coffee farms of the study area comprise various tree species as integral part of the farming system. An analysis of the composition of tree species shows the dominance of few tree species in the farms.

The diversity of tree species in coffee farms was reasonably comparable to that of the forest reserve. Species richness per plot was significantly higher $(\mathrm{p} \leq 0.05)$ for the forest reserve than the coffee farms. However, Shannon and Simpson diversity indexes showed that species diversity of the forest reserve was significantly lower $(\mathrm{p} \leq 0.05)$ than that of coffee farms when exotic trees included. But the diversity indexes of forest reserve significantly exceeded that of coffee farms without exotic species. On the other hand, individual-based and sample-based rarefaction curves did not show consistent differences in species richness and density between the two sites showing a comparable species richness of the two sites. In general, the diversity of tree species observed in this study reinforces the findings of other researchers which acknowledge the comparable conservation potential of coffee agroforestry system with natural forests.

\section{ACKNOWLEDGMENT}

Our genuine gratitude goes to Prof. Anders Ræbild and Dr. Richard Asare of the University of Copenhagen for their guidance in the entirety of this study. We are also grateful to the staffs at IITA Uganda, NaFORRI, NFA Mbale Rangers Branch, Sironko and Mbale districts government offices for their unlimited support. Our special thanks also go to Dr. Kato Stonewall and Mr. Wamboga Umar for their hospitality and guidance during the field works.

\section{REFERENCES}

Acharya, K.P., (2006). Linking trees on farms with biodiversity conservation in subsistence farming systems in Nepal. Biodivers. And Conserv., 15: 631-646. DOI: 10.1007/s10531-005-2091-7.

Adams, W.M. \& Hulme, D., (2001). If community conservation is the answer in Africa, what is the question? Oryx, 35,193-200. DOI:10.1046/j.1365-3008.2001.00183.x.

Bandeira, F.P., Martorell, C., Meave, J.A. \& Caballero, J., (2005). The role of rustic coffee plantations in the conservation of wild tree diversity in the Chinantec region of Mexico. Biodiversity Conservation, 14, 1225-1240. DOI: 10.1007/s10531-004-7843-2.

Berkes, F., (2009). Community conserved areas: policy issues in historic and contemporary context. Conservation Letters, 2,19-24. DOI: 10.1111/j.1755-263X.2008.00040.x.

Bhagwat, S.A., Willis, K.J., Birks, H.J.B. \& Whittaker, R.J., (2008). Agroforestry: a refuge for tropical biodiversity? Trends in ecology and evolution, 23, 261-67. DOI: 10.1016/j.tree.2008.01.005.

Colwell, R.K., Chao, A., Gotelli, N.J., Lin, S., Mao, C.X., Chazdon, R.L. \&Longino, J.T., (2012). Models and estimators linking individual-based and sample-based rarefaction, extrapolation and comparison of assemblages. Journal of Plant Ecology, 5,3-21. DOI: $10.1093 /$ jpe/rtr044.

Colwell, R.K., (2006, July). EstimateS: Statistical estimation of species richness and shared species from samples. Version 8. Retrieved July 10, 2012 from http://purl.oclc.org/ 
estimates.

Correia, M., Diabaté, M., Beavogui, P., Guilavogui, K., Lamanda, N. \& de Foresta, H., (2010). Conserving forest tree diversity in GuinéeForestière (Guinea, West Africa): the role of coffee-based agroforests. Biodiversity and Conservation, 19 (6), 1725-1747. DOI:10.1007/s10531-010-9800-6.

Curtis, J.T. \& McIntosh, R.P., (1950). The interrelations of certain analytic and synthetic phytosociological characters. Ecology, 31,434-455. DOI: 10.2307/1931497.

DeClerck, F.A.J., Chazdon, R., Holl, D.K., Milder, J.C., Martinez-Salinas, A., Imbach, P., Canet, L. \& Ramos, Z., (2010). Biodiversity conservation in human-modified landscapes of Mesoamerica: Past, present and future. Biological Conservation, 143: 2301-2313. DOI: 10.1016/j.biocon.2010.03.026.

Donald, P.F., (2004). Biodiversity impacts of some agricultural commodity production systems. Conserv. Biol., 18,17-37. DOI: 10.1111/j.1523-1739.2004.01803.x.

Escalante, E. E., (1985). Coffee and Agroforestry in Venezuela. Agroforestry Today, July-December, 5-7.

Gotelli, N.J. \& Colwell, R.K., (2001). Quantifying biodiversity: procedures and pitfalls in the measurement and comparison of species richness. Ecology Letters, 4, 379-391. DOI: 10.1046/j.1461-0248.2001.00230.x.

Katende, A.B., Birnie, A. \& Tengnas, B., (1995). Useful trees and shrubs for Uganda. Nairobi: Regional Soil Conservation Unit.

Klein, A.M., Cunningham, S.A., Bos, M. \& Steffan-Dewenter, I., (2008). Advances in pollination ecology from tropical plantation crops. Ecology, 89,935-943. DOI: 10.1890/07-0088.1.

Lopez-Gomez, A.M., Williams-Linera, G., Manson, R.H., (2008). Tree species diversity and vegetation structure in shade coffee farms in Veracruz, Mexico. Agriculture, Ecosystems \& Environment, 124 (3-4), 160-172. DOI:10.1016/j.agee.2007.09.008.

Mbale District Local Government, (2010). Five Year District Development Plan (2010/2011-2014/2015). Mbale: Mbale District Planning Unit.

McNeely, J.A. \& Schroth, G., (2006). Agroforestry and biodiversity conservation traditional practices, present dynamics, and lessons for the future. Biodiversity Conservation, 15,549-554. DOI: 10.1007/s10531-005-2087-3.

Muschler, R.G., (1997). Efectos de sombra de Erythrinapoeppigianasobre Coffeaarabica vars. Caturra y Catimor. In Memoriasdel XVIII SimposiumLatinoamericano de Cafeticultura, September 1997 (pp. 157-162). San Jose, Costa Rica.

Peeters, L.Y.K., Soto-Pinto, L., Perales, H., Montoya, G. \& Ishiki, M., (2003). Coffee production, timber, and firewood in traditional and Inga-shaded plantations in Southern Mexico. Agriculture, Ecosystems and Environment, 95(2), 481-493. DOI: 10.1016/S0167-8809(02)00204-9.

Perfecto, I., Rice, R.A., Greenberg, R. \& Van der Voort, M. E., (1996). Shade Coffee: A Disappearing Refuge for Biodiversity. BioScience,46(8), 598-608. DOI: 10.2307/1312989.

Schroth, G., Dan Foneseca, A.B., Harvey, C. A., Gascon, C., Vasconcelos, H. L. \& Izac, A. N., (2004). Agroforestry and biodiversity conservation in tropical landscapes. Washington, DC:Island Press.

Sorensen, T., (1948). A method of establishing groups of equal amplitude in plant sociology based on similarity of species content. Acta K. DanskeVidensk. Selsk. Biol. Skr. 5, 1-34. 
Negawo J. W., Beyene D. N.: The Role of Coffee Based Agroforestry System in Tree Diversity Conservation in Eastern Uganda

Sironko District Local Government, (2010). Five Year District Development Plan (2010/2011- 2014/2015). Sironko: Sironko Disrict Planning Unit.

Soto-Pinto, L., Perfecto, I., Castillo-Hernandez, J. \& Caballero-Nieto, J., (2000). Shade effect on coffee production at the northern Tzeltal zone of the state of Chiapas, Mexico. Agriculture, Ecosystems \& Environment, 80(1-2), 61-69. DOI: 10.1016/S0167-8809(00) 00134-1.

Terborgh, J. \& van Schaik, C.P., (2002). Why the world needs parks? In J. Terborgh, C.P. van Schaik, L. Davenport, \& M. Rao (Eds.). Making Parks Work: Strategies for Preserving Tropical Nature (pp. 3-14). USA: Island Press.

Vandermeer, J., Lawrence, D., Symstad, A. \& Hobbie, S. (2002). Effect of biodiversity on ecosystem function in managed ecosystems. In M. Loreau, S. Naeem \& P. Inchausti (Eds.). Biodiversity and Ecosystem Functioning: Synthesis and Perspectives (pp. 221-235). Oxford: Oxford University Press.

Western, D. \& Pearl, M.C., (1989). Conservation for the Twenty-First Century. New York: Oxford University Press.

Williams-Linera, G., (2002). Tree species richness complementarity, disturbance and fragmentation in a Mexican tropical montane cloud forest. Biodivers. Conserv.,11, 18251843. DOI: 10.1023/A:1020346519085.

Williams-Linera, G., Lopez-Gomez, A.M. \& Muniz-Castro, M.A., (2005). Complementariedad y patrones de anidamiento de especies de arbolesen el paisaje de bosque de niebladelcentro de Veracruz (Mexico). In G. Halffter, J. Soberon, P. Koleff \& A. Melic (Eds.). Sobrediversidadbiologica: el significado de lasdiversidadesalfa, beta y gamma (pp. 153-164). Zaragoza, Spain: m3m-MonografiasTercerMilenio, Vol 4. SEA, CONABIO, Grupo DIVERSITAS,CONACYT.

Wilson, E.O., (1988). Biodiversity. Washington, DC: National Academy Press. 